\title{
Use of bio-waste as fertiliser for the protected vegetable cultivation
}

\author{
Sử dụng chất thải hữu cơ làm phân bón canh tác rau trong nhà kính
}

Michael Henry BÖHME*

Department of Horticultural Plant Systems, Faculty of Life Sciences, Humboldt-Universität zu Berlin, Lentzeallee 75, D-14195 Berlin, Germany

\begin{abstract}
The number of biogas plants in Germany is increasing from 3,711 in 2007 to 8,075 in 2016. In these biogas plants, it occurred more than $50 \mathrm{Mt}$ digestate. Therefore, several investigations are started to use digestate as organic fertiliser mostly for field crop cultivation. Experiment with tomatoes was carried out were digestate was used as a supplement to the growing media in an amount of $5 \%, 15 \%$, and $25 \%$, compared with a treatment of mineral fertiliser and lupine wholemeal. The tomato yield was highest in the treatment with mineral fertilisation, the yield with $25 \%$ digestate was only a little lower. More experiments are necessary for particular regarding the amount and frequency of fertilization with digestate from biogas plants. In Germany and in Vietnam the number of sheep flocks is increasing, high amounts of uncleaned sheep wool are available. Because of the high amount of nutrients - especially nitrogen -, sheep wool pellets could be used as multi-functional fertiliser in vegetable cultivations. Four types of sheep wool pellets have been tested in protected cultivation. Tomatoes were cultivated in a greenhouse using substrate culture with perlite, bark compost, sheep wool slabs, respectively, and sheep wool pellets as fertiliser. Best growth and highest yield for tomatoes were obtained using pine bark and perlite as a substrate, both fertilised with sheep wool pellets. Based on the results of the yield and the analyses of the nutrient content in plants it seems that sheep wool pellets can be used, for the cultivation of vegetables in greenhouses.
\end{abstract}

Số lượng các nhà máy biogas tại CHLB Đức tăng từ 3.711 năm 2017 lên 8.075 năm 2016. Các nhà máy biogas sản sinh ra hơn 50 triệu tấn chất thải. Vì vậy đã có nhiều nghiên cứu liên quan đến sử dụng nguồn chất thải này làm phân bón hữu cơ cho canh tác nông nghiệp. Thí nghiệm với cà chua sử dụng chất thải biogas làm chất bổ sung dinh dưỡng cho giá thể trồng cây theo các tỷ lệ 5\%, 15\% và 25\% đối chứng với công thức sử dụng phân hóa học và bột nguyên vỏ họ đậu. Năng suất cà chua thu được từ các công thức bổ sung chất thải biogas đều cao hơn đối chứng, chỉ có công thức bổ sung $25 \%$ có năng suất thấp hơn. Tuy nhiên vẫn cần có những nghiên cứu tiêp theo về lượng và tần xuất sử dụng bón phân với chất thải từ nhà máy biogas. Ở Đức và ở Việt Nam số lượng đàn cừu đang tăng lên, một lượng lớn lông cừu phế phẩm phát sinh. Với hàm lượng dinh dưỡng cao, đặc biệt là nitơ', viên nén từ lông cừu phế phẩm có thể sử dụng làm phân bón đa chức năng cho trồng trọt. Nghiên cứu đã sử dụng 4 loại viên nén lông cừu làm phân bón trong điều kiện trồng có kiểm soát. Cà chua được trồng trong nhà kính với 3 loại giá thể là perlite, vỏ cây thông đã ủ hoai, thảm lông cừu với phân bón là viên nén từ lông cừu phế phẩm. Năng suất cao nhất và đem lại sinh trưởng tốt nhất cho cây cà chua là công thức sử dụng vỏ cây thông và perlite. Dựa trên kết quả về năng suất và phân tích dinh dưỡng trong cây và sản phẩm, nghiên cứu cho thấy sự phù hợp của viên nén từ lông cừu phế phẩm làm phân bón cho canh tác rau trong nhà kính.

Keywords: substrate culture, organic fertiliser, nitrogen supply, digestate, sheep wool pellets

\section{Introduction}

In many countries, in particular in South-East-Asia is a gap between demands of organic material for improving the soil fertility and to use as organic fertiliser. Often stables with a large amount of dung, as in Germany, are not available, respectively technologies for collecting and processing of bio-waste from rural households ore the municipalities (Gottschall, 1990). The best and sustainable way to convert the bio-waste from different sources in organic fertiliser is the use of digestate or composting. It can be observed different trends in agriculture one is related to the fertiliser supply of crops and another to reuse of organic residues. For sustainable cultivation of vegetables, the number of mineral fertilisers should be reduced and partly replaced with organic fertilisers. On the other hand, there are many sources of organic residues of which the reuse is not always clarified, e.g. digestate of biogas plants and e.g. animal wastes as sheep wool. Easily decomposable animal organic waste materials as horn- or blood powder are often not accepted in food production, due to health risks without hygienisation (BioAbfV, 2013). Other animalbased organic fertilisers, like poultry or farmyard manure, are more often used (Tüzel et al., 2004), but limited in the 
availability of specialised vegetable farms and in greenhouses for cultivating vegetables. Therefore, in organic horticultural farms, organic fertilisers based on plant material, e.g. coarse meal of castor cake (castor wholemeal) and crushed seeds of lupine (lupine wholemeal), is used (Müller et al., 2006). Investigations in many villages in Vietnam indicate a lack of organic fertilisers although there are many sources of biodegradable waste material (Nguyen, 1994; Dao and Nguyen, 2001; Böhme and Le, 2016). The deficiency of organic matters in the soil is also responsible for the low biological activity, unstable chemical and physical properties and erosion. The supply of organic matter should be increased for the integrated cropping and of course for organic farming (Kavetskiy et al., 2002).
The number of biogas plants in Germany is increasing from 3,711 in 2007 to 8,075 in 2016 (FNR, 2015). In this biogas plants occur more than $50 \mathrm{Mt}$ digestate (Table 1$)$. Therefore, based on several investigations the digestate is used almost completely as organic fertiliser mostly for field crop cultivation (BGK, 2016; ILL, 2014).

As it is visible in table 1, a high amount of the nutrients applied as fertilisers in Germany is already originated from digestate, concerning Nitrogen $8 \%$, Phosphate $42 \%$, and Potassium oxide $55 \%$ from all commercial sales fertilisers. Particular in horticulture digestate can be used as organic fertiliser because of the high demand for nutrient of most of the crops. Whereas in Vietnam more than $50 \%$ of the digestive were disposed to the environment ( $\mathrm{Cu}$ et al., 2012).

Table 1. Nutrients in digestate and commercial fertilisers (Kirsch, 2011)

\begin{tabular}{|c|c|c|c|c|}
\hline Nutrients & $\begin{array}{c}\text { Content in } \\
\text { Digestate (\% FM) }\end{array}$ & $\begin{array}{c}\text { Nutrients in } \\
50 \text { Mio. t digestate }\end{array}$ & $\begin{array}{l}{ }^{* *} \text { Commercial } \\
\text { fertiliser sales }\end{array}$ & $\begin{array}{c}\text { Digestate: Commercial } \\
\text { fertiliser sales (\%) }\end{array}$ \\
\hline Nitrogen $(\mathrm{N})$ & 0.25 & 125,000 t N & 1.57 Mio. t N & 8 \\
\hline Phosphate $\left(\mathrm{P}_{2} \mathrm{O}_{5}\right)$ & 0.20 & 100,000 t $_{2} \mathrm{O}_{5}$ & 0.24 Mio. t $\mathrm{P}_{2} \mathrm{O}_{5}$ & 42 \\
\hline Potassium $\left(\mathrm{K}_{2} \mathrm{O}\right)$ & 0.40 & $200,000 \mathrm{t} \mathrm{K}_{2} \mathrm{O}$ & 0.36 Mio. t $\mathrm{K}_{2} \mathrm{O}$ & 55 \\
\hline
\end{tabular}

Nevertheless, the quality of digestate as fertiliser depends on the composition of the raw material used (Friehe et al., 2013). Furthermore, the hygienic status of the raw material is of high importance, in particular, if the digestate is planned to use as organic fertiliser for vegetable cultivation because of the risk of contamination with diseases harmful for human health (Al Seadi and Lukehurst, 2012; Amon et al., 2013). However, the digestate have to follow the rights for use of fertilisers (Lindenblatt et al, 2007). In this document is described that biowaste and digestate have to be epidemical and phytohygienically harmless for humans and animals as well as the soil.

There are different quality regulations in Germany for use of raw materials depending on the so-called "Substance classes". Belong to Class I - as in many biogas plants used are renewable raw materials (ReRawMat) as maize, Sudan grass, millet, cereals and cereal silage; Class II - Animal waste as slurry and manure; Class III - biowaste from municipalities, households or industry. If this digestate are analysed with a determined frequency, maximum 12 times during one year, the biogas plant can receive a quality certificate following the highest standard for German products - RAL (Kirsch, 2015). For the grower very important is the nutrient content of the digestate in order to use it as fertiliser, it is visible in table 2 , there a slight difference between the digestate of plants using ReRawMat and those biogas plants using Biowaste.

Table 2. The total nutrient content of digestate in $\mathrm{kg} \mathrm{t}^{-1}$ fresh matter (FM) mean and range for most important nutrients (Haber and Kluge, 2008)

\begin{tabular}{|c|c|c|c|c|c|}
\hline \multirow[t]{2}{*}{ Nutrients } & & \multicolumn{2}{|c|}{${ }^{*}$ Mean } & \multicolumn{2}{|c|}{${ }^{* *}$ Range } \\
\hline & & ${ }^{* * *}$ ReRawMat & *Bowaste & ${ }^{* * *}$ ReRawMat & *Bowaste \\
\hline Nitrogen & $\mathrm{N}$ & 4.70 & 4.80 & $3.90-5.50$ & $3.40-5.90$ \\
\hline Ammonium & $\mathrm{NH}_{4}-\mathrm{N}$ & 2.70 & 2.90 & $2.10-3.30$ & $2.30-3.80$ \\
\hline Phosphorous & $\mathrm{P}_{2} \mathrm{O}_{5}$ & 1.80 & 1.80 & $1.20-2.10$ & $1.20-2.40$ \\
\hline Potassium & $\mathrm{K}_{2} \mathrm{O}$ & 5.00 & 3.90 & $3.80-6.00$ & $2.20-4.80$ \\
\hline Magnesium & $\mathrm{MgO}$ & 0.84 & 0.70 & $0.47-1.04$ & $0.43-1.00$ \\
\hline Calcium & $\mathrm{CaO}$ & 2.10 & 2.10 & $1.50-2.60$ & $1.50-2.70$ \\
\hline Sulphur & $S$ & 0.33 & 0.32 & $0.26-0.41$ & $0.22-0.39$ \\
\hline
\end{tabular}

Note: *arithmetic mean; **range of $20-80$ Quantile; ***plants use renewable raw materials (ReRawMat); ****plants use Biowaste

There are biogas plants constructed with the aim to supply the energy in different agricultural buildings, furthermore, the waste heat can be used for heating of greenhouses. In the south of Berlin was established as a biogas plant by the Steinhoff Family Holding Ltd. with 844 kW electrical power. Besides this plant 10ha greenhouse complex was built mainly for tomato and cucumber production.
The waste heat of the biogas plant (7.2 MW per year) is used for heating of this greenhouse complex. The biogas plant is using mainly renewable raw materials as maize, Sudan grass, Millet, Cereal silage and others, cultivated of their own 3,000 ha agriculture land. There are several biowaste materials useful in agriculture as fertiliser or for other purposes (BioAbfV, 2013). In some cases, the existing 
waste materials have to be tested, whether they are convenient for further use in agriculture or horticulture to avoid negative effects on the environment. In Germany, high amounts of uncleaned sheep wool are available, currently used mainly as waste material.

In Vietnam the number of sheep flocks is increasing, so a similar problem can occur in the future (Redazione, 2016). Sheep wool was already successfully tested as a substrate for cultivating cucumbers in the greenhouse (Böhme et al., 2008). Its high amount of nutrients, especially nitrogen, suggests the possibility of its use as an organic fertiliser, after processing in pellets.

In this study two aims of the researchers were followed:

1. To investigate the use of digestate of a biogas plant as an organic fertiliser for tomatoes cultivated in a soilless substrate culture.

2. To develop sheep wool pellets as multi-functional fertiliser in protected vegetable cultivation. First, pellets with a good structure and an acceptable decomposition rate were developed (IfN, 2008). Second, Pellets were used as fertiliser mixed in different growing media for tomatoes cultivated in a greenhouse.

\section{Materials and methods}

\subsection{Digestate used as organic fertiliser in substrate culture}

\subsubsection{Digestate}

Digestate from the biogas park in Felgentreu in the state Brandenburg managed by Steinhoff family holding, biogas plant tank A5EL was used. In the biogas plant only plant material as rye, maize, Sudan-grass, and millet were utilized, the fresh digestate had a soft muddy consistency with a dry matter (DM) of $10.64 \%$ and $\mathrm{pH} 8.4$ (Hoffmann, 2011). The nutrient content in the digestate used in the experiment is shown in Table 3.

Table 3. Nutrient content in the digestate from the biogas park in Felgentreu - tank: A5EL

\begin{tabular}{lcc} 
Nutrient & ${ }^{*}$ Content in kg $^{-1} \mathrm{FM}$ & ${ }^{* *}$ Content in \% DM \\
\hline Nitrogen total & 6.38 & 6.72 \\
Ammonium & 3.7 & \\
Phosphorous & 1.23 & $2.67\left(\mathrm{P}_{2} \mathrm{O}_{5}\right)$ \\
Potassium & 6.4 & $7.30\left(\mathrm{~K}_{2} \mathrm{O}\right)$ \\
Magnesium & 0.6 & $0.90(\mathrm{MgO})$ \\
Calcium & 1.2 & $1.60(\mathrm{CaO})$ \\
\multicolumn{2}{c}{ Note: ${ }^{*}$ fresh matter (FM); ${ }^{* *}$ dry matter (DM) }
\end{tabular}

\subsubsection{Cultivation of tomato using digestate as fertiliser}

Tomatoes (Lycopersicon esculentum Mill. cv. 'Aromata') were planted in containers $(7 \mathrm{~L}, 2580 \mathrm{~g} \mathrm{FM}$, water capacity 30-40\%) filled with the Growing media ,Gramoflor', $80 \%$ white peat and $20 \%$ black peat, pH 5.4 - 6.2, one enriched with one dosage complex fertiliser N/P/K-14/16/18 $\mathrm{kg} \mathrm{m}^{-3}$.
Substrate culture was used with 6 plants (containers) for each of the five variants. The nutrient solution for the control variant (mineral nutrient supply) was calculated with the HYDROFER computer programme (Böhme, 1993).

The variants of the experiments with digestate are visible in table 4 which is designed with a similar methodology as the previous study (Hoffmann, 2011). The water supply was carried out by hand with an increasing amount adapted, on the estimated demand of the tomato plants with 200 to $800 \mathrm{ml}$ per variants $1,2,3$ and 4, but 0 to 800 $\mathrm{ml}$ for variant 5 . The basic composition of the nutrient solution was N (160 ppm), P (50), K (250), Ca (180), Mg (80), $\mathrm{Fe}(6), \mathrm{HCO}_{3}{ }^{-}$(70). The EC-value was adjusted to $2.3 \mathrm{mS} \mathrm{cm}$ ${ }^{1}$ and the target $\mathrm{pH}$ value was 5.7. Cultivation time was 70 days, from $21^{\text {st }}$ June until $31^{\text {st }}$ August.

Table 4. Variants with a supplement of digestate to the substrate for tomato cultivation

\begin{tabular}{llcl} 
No. & Fertilization & Quantity & Frequency \\
\hline 1 & Digestate & $* 5 \%$ & one time \\
2 & Digestate & $15 \%$ & one time \\
3 & Digestate & $25 \%$ & one time \\
4 & Lupine wholemeal & $50 \mathrm{~g}$ & one time \\
5 & Nutrient solution & $200 \mathrm{ml}$ & daily \\
\multicolumn{3}{c}{ Note: $* \%$ of total substrate mass in the container (2580g) }
\end{tabular}

The total amount of fertilisers applied to the tomato plants in this experiment was different, for all nutrients except Phosphorus the highest dosage was applied with a mineral nutrient solution (Table 5).

Table 5. The total amount of nutrients applied during 70 days of growth of tomato plants

\begin{tabular}{lrrrr} 
Nutrients & Digestate & Digestate & Digestate & Nutrient \\
& $\mathbf{5 \%}$ & $\mathbf{1 5 \%}$ & $\mathbf{2 5 \%}$ & solution \\
\hline $\mathrm{N}$ & 0.990 & 2.723 & 4.457 & 10.489 \\
$\mathrm{P}$ & 4.152 & 3.200 & 0.793 & 3.250 \\
$\mathrm{~K}$ & 13.754 & 8.533 & 4.261 & 16.347 \\
$\mathrm{Mg}$ & 0.358 & 0.513 & 10.180 & 5.404 \\
$\mathrm{Ca}$ & 3.524 & 3.834 & 4.144 & 14.148
\end{tabular}

\subsection{Experiment with sheep wool pellets as fertiliser}

\subsubsection{Characteristics of sheep wool pellets}

Before using sheep wool pellets as fertiliser, different combinations of sheep wool with other components (cellulose, starch, casein) were tested in order to find optimal physical and appropriate technological characteristics of the pellets (IfN, 2008). The $\mathrm{pH}$ ranged between 7.5-9 and the EC between 6.3-8.8 $\mathrm{mS} \mathrm{cm}^{-1}$ (Boehme et al., 2008). The appropriate values for the cultivated crops were reached through dilution and leaching before and during cultivation. Analyses of imbibition and water retention proved that the pellets take up more than 20 times their weight in water within 15 minutes (IfN, 2008). For the experiments, pure sheep wool pellets were used. 


\subsubsection{Tomato cultivation in greenhouse using sheep wool pellets}

Tomatoes (Lycopersicon esculentum Mill. cv. 'Alkasar' GR) were planted in containers ( $8 \mathrm{~L}$ volume) filled with perlite (average dry density of $120 \mathrm{~kg} \mathrm{~m}^{-3}$ ) and in the second variant with pine bark compost. Substrate culture with trickle irrigation was used and two different fertilisation levels. The plant density was of 2.5 plants $\mathrm{m}^{-2}$ with 16 plants (containers) for each of the four variants. The nutrient supply was calculated with the HYDROFER computer programme (Böhme, 1993) the required amounts of fertilisers, salts, and acids were adjusted on the growth stage. In two variants, the substrate slabs were treated with 100 g sheep wool pellets per plant and irrigated with a reduced nutrient solution without any mineral nitrogen. The harvest started on $28^{\text {th }}$ September and continued until $15^{\text {th }}$ February.

The experiments with digestate comprised 6 plants per treatment ( 6 replications) randomly distributed and in the experiment with sheep wool pellets 3 plants (3 replications). Results were analysed using the one way ANOVA which were used to evaluate differences between treatments at a significance level of 95\% $(P<0.05)$ by SPSS 17.0 software package and mean separation was done by Tukey-test.

\section{Results and discussion}

\subsection{Tomato cultivation with digestate as organic fertiliser}

Tomatoes were cultivated for 70 days in a greenhouse with three inflorescences. In the parameters regarding leaf FM and number of fruits, almost all values of variants were significantly lower than those with mineral nutrition (Table 6). On the second place regarding some of the parameters was the variant 3 with $25 \%$ supplement of digestate. This variant was even better than the tomatoes fertilized with lupines wholemeal. Besides the lower results with organic fertilisers, the visual evaluation showed disorders and deficiencies of nutrients on the leaves and fruits.

Table 6. Shoot and leave FM, number of fruits and fruit yield of tomato plants cultivated with digestate, lupine wholemeal and nutrient solution

\begin{tabular}{|c|c|c|c|c|}
\hline & $\begin{array}{l}\text { Shoot FM } \\
\text { (g/plant) }\end{array}$ & $\begin{array}{l}\text { Leaf FM } \\
\text { (g/plant) }\end{array}$ & $\begin{array}{l}\text { Fruits/ } \\
\text { plants }\end{array}$ & $\begin{array}{c}\text { Fruit yield } \\
\text { (g/plant) }\end{array}$ \\
\hline Digestate $5 \%$ & 118.67 & $218.83^{b}$ & $5.00^{b}$ & $520.83^{a b}$ \\
\hline Digestate 15\% & $131.00^{a b}$ & $281.67^{b}$ & $7.33^{b c}$ & $739.33^{b c}$ \\
\hline Digestate $25 \%$ & $146.67^{a}$ & $353.33^{b}$ & $10.17^{a b}$ & $936.33^{a b}$ \\
\hline $\begin{array}{l}\text { Lupines } \\
\text { wholemeal }\end{array}$ & $145.33^{a}$ & $310.67^{b}$ & $8.17^{b c}$ & $847.83^{a b c}$ \\
\hline Nutrient & $194.67^{\mathrm{a}}$ & $679.00^{a}$ & $12.83^{\mathrm{a}}$ & $1123.50^{a}$ \\
\hline
\end{tabular}

solution

Note: different letters $(a-c)$ indicate significant differences in the treatments (Tukey-test, $P<0.05)$.
It is noticeable the fruit yield obtained in the variant with digestate $(25 \%)$ is $17 \%$ lower compared to the variant with nutrient solution. On the other hand, the amount of nitrogen applied is $42 \%$ lower compared to mineral fertilisation with nutrient solution. Therefore, the amount of digestate as organic fertiliser should be increased. In order to avoid too high concentration of nitrogen, another frequency could be tested, e.g. two or three times during the vegetation, considering the last fertilisation will be conducted two weeks before the last harvesting.

Table 7. Nutrient content in the leaves of tomato plants cultivated with digestate, lupine wholemeal and nutrient solution (g/kg DM; except N in \%/DM)

\begin{tabular}{lccccc} 
& $\mathbf{N}$ & $\mathbf{P}$ & $\mathbf{K}$ & $\mathrm{Ca}$ & $\mathbf{M g}$ \\
\hline Digestate 5\% & $1.14^{\mathrm{b}}$ & $5.25^{\mathrm{ab}}$ & $29.30^{\mathrm{b}}$ & $34.72^{\mathrm{a}}$ & $5.68^{\mathrm{b}}$ \\
Digestate 15\% & $1.13^{\mathrm{b}}$ & $5.19^{\mathrm{ab}}$ & $27.23^{\mathrm{bc}}$ & $27.47^{\mathrm{a}}$ & $5.14^{\mathrm{b}}$ \\
Digestate 25\% & $1.31^{\mathrm{b}}$ & $5.57^{\mathrm{b}}$ & $33.05^{\mathrm{b}}$ & $32.55^{\mathrm{a}}$ & $5.96^{\mathrm{b}}$ \\
$\begin{array}{l}\text { Lupines } \\
\text { wholemeal }\end{array}$ & $1.93^{\mathrm{b}}$ & $4.78^{\mathrm{c}}$ & $20.41^{\mathrm{c}}$ & $31.88^{\mathrm{a}}$ & $6.28^{\mathrm{b}}$ \\
$\begin{array}{l}\text { Nutrient } \\
\text { solution }\end{array}$ & $3.96^{\mathrm{a}}$ & $7.97^{\mathrm{a}}$ & $45.62^{\mathrm{a}}$ & $34.80^{\mathrm{a}}$ & $8.68^{\mathrm{a}}$
\end{tabular}

Note: different letters $(a-c)$ indicate significant differences in the treatments (Tukey-test, $P<0.05)$.

The nutrient contents (excluding Ca amount) in the leaves were highest significantly in the variants treated with nutrient solution (Table 7), as it was expected because the higher application of nutrients in comparison to the organic fertilisation (see Table 5). Calcium uptake is more depended on the transpiration rate, if no differences in the uptake are often also not different regarding the content in the leaves (Armstrong and Kirkby, 1979.

\subsection{Tomato in substrate culture with sheep wool pellets as fertiliser}

In this experiment in both substrates, about $3 \mathrm{~kg}$ tomatoes per $\mathrm{m}^{2}$ were harvested with a standard nutrient solution (Böhme, 1993) (Fig. 1).

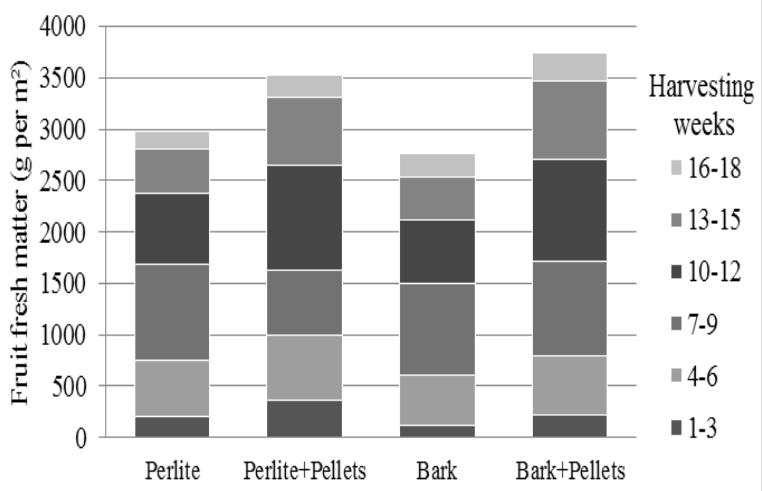

Figure 1. The yield of tomatoes cultivated in a greenhouse using perlite and pine bark with mineral and organic (sheep wool pellets) fertilisation. Differences are not significant $(p<0.05)$.

In the perlite substrate - due to the organic fertilisation by the sheep wool pellets - the total yield was increased by $20.6 \%$, whereas a $35.4 \%$ increase was achieved with bark compost. Inden and Torres (2004) had already reported an 
increase in the yield on the perlite substrate by adding organic material. Probably, there is a relationship between the slow nitrogen release from the sheep wool and the plant growth as well as the yield. Using sheep wool pellets, in the harvesting weeks 10-12 and 13-15, the fruit load was much higher than in the first weeks in comparison with the substrates without pellets (Fig. 1). The fruit quality parameters as mineral contents and the sugar/acid ratio were not affected by substrate or fertilisation (Table 10). The values were in the ranges indicated by Souci et al. (1991) and Liebster (1991).

Table 10. Nutrient content of tomato fruits cultivated in perlite and bark compost affected by the addition of $100 \mathrm{~g}$ sheep wool pellets per plant

\begin{tabular}{lrrrrr}
$\begin{array}{l}\text { Content } \\
{[\mathrm{mg} / 100 \text { g FM] }}\end{array}$ & $\begin{array}{r}\text { Perlite }+ \\
\text { mineral fertilisation }\end{array}$ & Perlite + pellets & $\begin{array}{r}\text { Bark + } \\
\text { mineral fertilisation }\end{array}$ & $\begin{array}{r}\text { Bark + } \\
\text { pellets }\end{array}$ & $\begin{array}{r}\text { *Literature } \\
\text { mean values }\end{array}$ \\
\hline $\mathrm{NO}_{3}{ }^{-}$ & 90.31 & 103.19 & 96.26 & 96.07 & $<500$ \\
$\mathrm{P}$ & 18.73 & 20.28 & 19.21 & 18.31 & 25 \\
$\mathrm{~K}$ & 242.75 & 236.71 & 257.57 & 244.81 & 295 \\
$\mathrm{Mg}$ & 9.66 & 9.84 & 11.06 & 9.70 & 20 \\
$\mathrm{Ca}$ & 6.08 & 5.47 & 5.20 & 5.48 & 14 \\
Sugar/Acid-Ratio & 9.70 & 9.8 & 10.10 & 8.80 & 7
\end{tabular}

Note: *(Liebster, 1991; Souci et al., 1991)

\section{Conclusion}

It is possible to use biogas digestate as fertiliser as well as a nutrient source for agriculture. Nevertheless, the number of nutrients applied should be similar whether as mineral or organic fertilizer, to avoid differences in yield and nutrient content. The higher amount of digestate with $25 \%$ added to the substrate can be recommended. The frequency of fertilization and amount of digestate adding to substrates should be investigated. The advantage of the use of digestate is the higher economy because using a recycled product. Further investigations with different types of digestate as available e.g. in Vietnam are recommended. Sheep wool pellets can be used as organic fertiliser in integrated or organic farming of horticultural crops, also in different combinations with mineral fertilisers The effects as the fertiliser of sheep wool pellets are maybe dependent on the cultivation period and are more pronounced in crops with longer cultivation time because the nutrients are slowly available. Further research is necessary in this regard. The first results are encouraging to investigate other expectable effects by using sheep wool pellets regarding the stimulation of microbial activity and increase of nutrient availability (IfN, 2008). Furthermore, experiments aimed to improve the physical properties of soils and substrates by use of sheep wool pellets are needed. It seems it is a potential to increase the amounts of the organic fertilisation if the frequency of application will be increased.

\section{References}

[1] Al Seadi, T. and Lukehurst, C. T. 2012. Quality management of digestate from biogas plants used as fertiliser. IEA Bioenergy, Task 37 - Energy from Biogas.

[2] Amon, T., Döhler, H., Grebe, S., Klages, S., Roth, U., Wilken, D. and Wulf S. 2013. Qualität und Verwertung des Gärrückstandes. Fachagentur Nachwachsende Rohstoffe e. V. (FNR). ISBN 3-00-014333-5, p.184-201
[3] Armstrong, M. J. and E. A. Kirkby, 1979. The influence of humidity on the mineral composition of tomato plants with special reference to calcium distribution. Plant and Soil, 52(3): 427-435.

[4] BGK (Bundesgütegemeinschaft Kompost). 2016. Humuswirtschaft \& Kompost aktuell 08/09

[5] BioAbfV. 2013. In German: Bioabfallverordnung in der Fassung der Bekanntmachung vom 4. April (Biological Waste Ordinance as promulgated on 4 April). (BGBI. I S. 658).

[6] Böhme, M. 1993. Parameters for calculating the nutrient solution for hydroponics. Proc. Int. Soc. for Soilless Culture, 8: 85-96.

[7] Böhme, M. and Le, H. A. 2016. Sustainable Technology for Using Bio-Waste in Rural and Urban Regions in South- and South-East-Asia. Procedia CIRP, 40: 547550. doi: 10.1016/j.procir.2016.01.131.

[8] Böhme, M., Schevchenko, J., Herfort, S. and Pinker, I. 2008. Cucumber grown in sheep wool slabs treated with biostimulator compared to other organic and mineral substrates. Acta Hort. 779: 299-305.

[9] Cu, T. T. T., Pham, H. C., Le, T. H., Nguyen, V. C., Le, X. A., Nguyen, X. T. and Sven G. S. 2012. Manure management practices on biogas and non-biogas pig farms in developing countries using livestock farms in Vietnam as an example. Journal of Cleaner Production, 27: 64-71.

[10] Dao, C. T., and Nguyen, X. T. 2001. Composting of organic fraction of household waste for fertilization of clean vegetable production. Proceedings workshops „Land use systems, use of substrates and biotechnology in horticulture" at Hué Agricultural University and „Sustainable Horticulture in Vietnam" at Hanoi-University of Agriculture, 44-49.

[11] FNR. 2015. Fachverband Biogas e. V. 2014. und DBFZ.

[12] Friehe, J., Schattauer A. and Weiland P. 2013. 
Beschreibung ausgewählter Substrate. Leitfaden Biogas - Von der Gewinnung zur Nutzung. Fachagentur Nachwachsende Rohstoffe e. V. (FNR), 68-76.

[13] Gottschall, R. 1990. Kompostierung: optimale Aufbereitung und Verwendung organischer Materialien im ökologischen Landbau. 4. ed. C.F. Müller, Karlsruhe, ISBN 3-7880-9798-1.

[14] Haber, N. and Kluge, R. 2008. Inhaltsstoffe von Gärprodukten und Möglichkeiten zu ihrer geordneten pflanzenbaulichen Verwertung. Projektbericht Baden Württemberg Landwirtschaftliches Technologiezentrum Augustenberg.

[15] Hoffmann, K. 2011. Die Verwendung von Gärprodukten aus Biogasanlagen zur Kultivierung von Tomatenpflanzen, Bachelor-Arbeit an der Humboldt-Universität zu Berlin, FG Gärtnerische Pflanzensysteme, 52 p.

[16] IfN. 2008. Development of a multi-functional fertiliser based on renewable resources for organic and conventional horticulture. Report of the Aif collaboration project, Lauchhammer (in German), 83 p.

[17] ILL (International Labmate Limited) 2014. The Use of Digestate as an Organic Fertiliser. Oak Court Business Centre.

[18] Inden, H. and Torres, A. 2004 Comparison of four substrates on the growth and quality of tomatoes. Acta Hort. 644: 205-210.

[19] Kavetskiy S., Kraynyuk M., Hofman G., Böhme M., and Cleemput O. 2003. Soil Quality and fertilization. Tempus Tacis, NAUU, Kiev, ISBN 966-8006-20-8.
[20] Kirsch A. 2011. Gärprodukte- Eine bedeutende Nährstoffquelle. H\&K aktuell 6, p. 6.

[21] Kirsch A. 2015. Untersuchung von Gärprodukten. H\&K aktuell 10: 6-7

[22] Liebster, G. 1991. Warenkunde Obst\&Gemüse. Vol. 2 Gemüse. morion, Düsseldorf.

[23] Lindenblatt C., Wendland M., Reitberger F., Müller C., Lebuhn M., Bachmaier H., Gehling R. 2007. Biogashandbuch Bayern - Materialienband, Kap. 1.6.

[24] Müller, T., von Fragstein and Niemsdorff, P. 2006. Organic fertilisers derived from plant materials Part I: Turnover in soil at low and moderate temperatures. J. Plant Nutr. Soil Sci., 169: 255-264.

[25] Nguyen, D. L. 1994. Application of microbial cellulose for cellulose material treatment. Research report, University Ho-Chi-Minh, Vietnam.

[26] Redazione, A. and Doan, D. V. 2016. Goats, sheep, South Vietnam Agricultural Science Institute, SVASI, Vietnam, http://alimentasrl.com/1175/vietnamsheep-goat-farming-making-comeback.html.

[27] Souci, S. W., Fachmann, W. and Kraut, H. 1991. Der kleine Souci-Fachmann-Kraut. Die Zusammensetzung der Lebensmittel, Nährwert-Tabellen, Wissenschaftliche Verlagsges. Stuttgart, 2nd Edition.

[28] Tüzel, Y., Gümüs, M., Özetkin, G.B., Tüzel, I.H., Ongun, A.R. and Eltez R. Z. 2004. Organic Tomato production in the greenhouse. Acta Hort. 659: 729-732. 